\title{
Pembaruan Pilar Hukum Pidana Dalam RUU KUHP
}

\author{
Faisal1, Muhammad Rustamaji ${ }^{2}$
}

1Fakultas Hukum Universitas Bangka Belitung, E-mail: progresif_lshp@yahoo.com 2Fakultas Hukum Universitas Sebelas Maret, E-mail: hitachi_ajie@yahoo.com

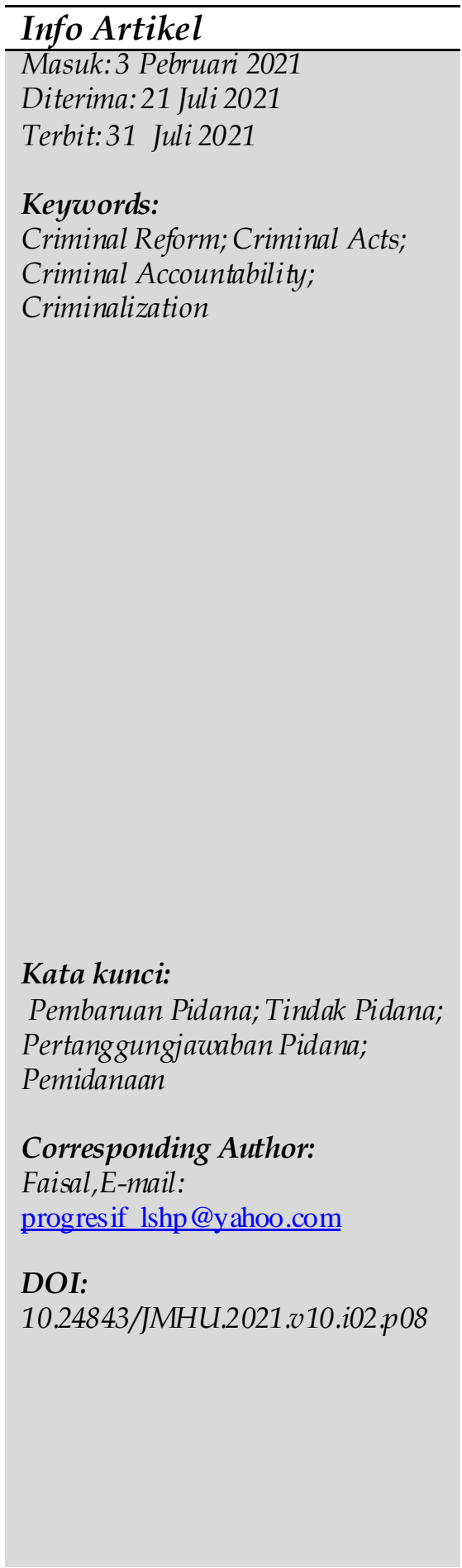

\begin{abstract}
The basic idea underlying the reform of the Criminal Code Bill has an impact on reforming the pillars of criminal law. The purpose of this research is to find out the new direction of criminal law policy regarding criminal acts, criminal responsibility and punishment. The research method uses normative legal research. The results of the research study in the discussion section are the reform of the pillars of criminal law, namely criminal acts, criminal liability, and punishment oriented to the basic idea of the value of balance. The reform of the pillars of criminal acts is aimed at broadening the meaning of the legality principle which provides space for living law as a source of law and also creates juridical terminology regarding criminal acts. The pillar of criminal responsibility accommodates the principle of no crime without error. The pillar of punishment is that the purpose of punishment is no longer synonymous with retaliation, but there are efforts to improve the behavior of the perpetrators of crime. The changes in the three pillars are influenced by the basic idea of balancing the values of Pancasila, namely the values of Divinity, Humanity, and Society. Recommendations in strengthening the direction of criminal law reform are needed in formulating criminal provisions outside the Draft Criminal Code that must be in accordance with the basic idea of balance which is the ideal of criminal law reform law.
\end{abstract}

\begin{tabular}{l}
\hline Abstrak \\
\hline Ide dasar yang melandasi pembaruan RUU KUHP \\
berdampak pada pembaruan pilar hukum pidana. \\
Tujuan penelitian untuk mengetahui arah baru \\
kebijakan politik hukum pidana mengenai tindak \\
pidana, pertanggungjawaban pidana dan pemidanaan. \\
Metode penelitian menggunakan penelitian hukum \\
normatif. Hasil kajian penelitian dalam bagian \\
pembahasan ialah pembaruan pilar hukum pidana \\
yakni tindak pidana, pertanggungjawaban pidana, dan \\
pemidanaan berorientasi pada ide dasar nilai \\
keseimbangan. Pembaruan pilar tindak pidana tertuju \\
pada perluasan makna asas legalitas yang memberikan \\
ruang pada hukum yang hidup sebagai sumber \\
hukum dan melahirkan pula terminologi yuridis \\
mengenai tindak pidana. Pilar pertangungjawaban \\
pidana mengakomodasi asas tiada pidana tanpa \\
kesalahan. Pilar pemidanaan bahwa tujuan
\end{tabular}


pemidanaan tidak lagi identik pembalasan akan tetapi ada upaya memperbaiki perilaku dari pelaku kejahatan. Perubahan ketiga pilar tersebut dipengaruhi oleh ide dasar keseimbangan nilai Pancasila yaitu nilai Ketuhanan, Kemanusiaan, dan Kemasyarakatan. Rekomendasi dalam memperkuat arah pembaruan hukum pidana diperlukan dalam merumuskan ketentuan pidana di luar RUU KUHP harus sesuai dengan ide dasar keseimbangan yang menjadi cita hukum pembaruan hukum pidana

\section{Pendahuluan}

Upaya pembaruan hukum pidana nasional telah muncul sejak era kemerdekaan. Diawali dengan diterbitkan Pasal II Aturan Peralihan UUD 1945 menjadi dasar hukum untuk menghindari kekosongan hukum. Peraturan yang ada (KUHP lama) masih tetap diberlakukan dan di masa mendatang diharapkan lahir KUHP yang sesuai dengan semangat proklamasi sebagai bangsa yang merdeka. Ditegaskan kembali dalam Undang-Undang No.1 Tahun 1946 Jo. UU No.73 Tahun 1958 dimana peraturan hukum pidana tidak boleh bertentangan dengan kedudukan negara Indonesia sebagai negara merdeka.

Wawasan pembaharuan hukum pidana tercermin dalam Seminar Hukum Nasional 11 Maret 1963. Disebutkan resolusi KUHP baru itu bagian umum yang memuat asas-asas umum (fundamental) antara lain asas legalitas hendaknya disusun secara progresif sesuai dengan kepribadian Indonesia dan perkembangan revolusi, setelah mempelajari aturan-aturan pidana umum dalam KUHP di negara lain. ${ }^{1}$ Resolusi yang dihasilkan dalam Seminar (1963) merupakan wawasan atau pemikiran hukum nasional yang berkembang dalam rangka pembaruan hukum pidana yang mencerminkan kemerdekaan bangsa Indonesia.

Paradigma baru pembaruan hukum pidana nasional tidak sekedar mengganti norma pidana secara teknis, hal terpenting yaitu merefleksikan apa yang dicita-citakan bangsa Indonesia sebagai negara merdeka, adil dan makmur. Pembaruan hukum pidana nasional berpijak pada visi dan misi yang melingkupi RUU KUHP.

Visi dari RUU KUHP harus adanya keunggulan secara sistematik baik itu secara struktural, subtantif dan kultural. Hal ini menjadi alasan dan tujuan untuk mengganti KUHP lama (WvS) warisan kolonial Belanda. Visi itu oleh Muladi digambarkan pada tujuan masa depan dalam mewujudkan hukum pidana nasional yang berlandaskan Pancasila, Konstitusi, HAM serta asas-asas hukum umum yang diakui masyarakat beradab. Selain itu, misi utama RUU KUHP yaitu proses dekolonialisasi melalui rekodifikasi terbuka secara sistematik. Artinya, tidak dilakukan dengan cara fragmentaris atau dimaksudkan tidak tambal sulam. ${ }^{2}$

\footnotetext{
${ }^{1}$ Barda Nawawi Arief, Kumpulan Hasil Seminar Hukum Nasional Ke I s/d VIII Dan Konvensi Hukum Nasional 2008 Tentang Undang-Undang Dasar 1945 Sebagai Landasan Konstitusional Grand Design Sistem Dan Politik Hukum Nasional (Semarang: Badan Penerbit Universitas Diponegoro, 2011). h. 6

${ }^{2}$ Muladi and Diah Sulistyani, Catatan Empat Dekade Perjuangan Turut Mengawal Terwujudnya KUHP Nasional (Bagian I, 1980-2020) (Semarang: Universitas Semarang, 2020). h. 31\&37
} 
Naskah Akademik RUU KUHP yang ditulis pada Tahun 2015 dan diterbitkan oleh BPHN Kementerian Hukum dan HAM, disitu disebutkan adanya tiga pilar pembaharuan hukum pidana nasional. Ketiga pilar tersebut memfokuskan pada hal utama dalam hukum pidana, yaitu tindak pidana, pertanggungjawaban pidana, serta pidana dan pemidanaan.

Barda Nawawi Arief menegaskan jika konsep RUU KUHP disusun dan bertolak pada 3 (tiga) materi atau subtansi dan masalah pokok dalam hukum pidana; tindak pidana, kesalahan atau pertanggungjawaban pidana, serta pemidanaan. ${ }^{3}$ Tindak pidana dalam ilmu hukum pidana sering dihubungkan dengan perumusan perbuatan yang dilarang. Norma pidana yang mengkualifikasikan suatu perbuatan diancam dengan pidana. Membatasi dan mengumumkan perbuatan yang dilarang menjadi salah satu fungsi hukum pidana. Segala perilaku atas sebuah perbuatan ditetapkan dan diatur sedemikian rupa agar perbuatan masyarakat dapat terhindar dari ancaman pidana. Hukum pidana, dirancang untuk memelihara ketertiban, sama halnya melindungi kepentingan publik dan pribadi. ${ }^{4}$

Eksistensi hukum pidana tidak dapat terpisahkan dari masyarakat itu sendiri. Norma hukum pidana dipercayai dapat menjadi salah satu norma yang memberikan perlindungan aspek moralitas masyarakat dan kepentingan masyarakat itu sendiri, berupa ketertiban dan kedamaian. 5 Penormaan dasar patut dipidananya suatu perbuatan untuk dinyatakan sebagai tindak pidana atau bukan di dalam KUHP masih memegang teguh pada legalitas formal. Tindak pidana merupakan perbuatan yang harus dituliskan dalam peraturan pidana tertulis. Dengan demikian, tiada suatu pidana jika tidak didasarkan pada ketentuan tertulis. Terlebih lagi KUHP (WvS) tidak memiliki definisi yuridis apa itu yang dimaksud dengan tindak pidana. Menjadi keliru, apabila Pasal 1 Ayat (1) KUHP dipahami sebagai pengertian tindak pidana. Lebih tepat Pasal itu disebut sebagai sumber atau dasar hukum ditetapkannya tindak pidana.

Problem pokok selanjutnya dalam hukum pidana ialah prihal pertanggungjawaban. Segala tingkah laku dan perbuatan masyarakat diatur oleh hukum. Secara umum, perbuatan yang melanggar hukum wajib dipertanggungjawabkan. Pertanggungjawaban pidana merupakan konsekuensi dari dilakukannya kejahatan. Menentukan salah tidaknya seseorang adalah bagian penting prihal kemampuan bertanggungjawab. Penjatuhan pidana akan ditentukan dari kejahatan yang dilakukan apakah dapat dimintakan pertanggungjawaban di depan hukum atau tidak. ${ }^{6}$

Pertanggungjawaban pidana kajiannya pada aspek kesalahan yang secara spesifik fokus pada orang dalam arti pelaku delik. Pertanggungjawaban pidana biasanya selalu dihubungkan dengan doktrin hukum pidana mengenai aliran monisme yang menjadikan satu antara tindak pidana dengan pertanggungjawaban pidana, sebaliknya

\footnotetext{
${ }^{3}$ Barda Nawawi Arief, Kebijakan Hukum Pidana Perkembangan Penyusunan Konsep KUHP Baru (Jakarta: Kencana, 2011). h. 79

${ }^{4}$ Muhaimin Muhaimin, "Restoratif Justice Dalam Penyelesaian Tindak Pidana Ringan," Jurnal Penelitian Hukum De Jure 19, no. 2 (June 26, 2019): 185, https://doi.org/10.30641/DEJURE.2019.V19.185-206. h. 6

${ }^{5}$ Yoserwan, "Fungsi Sekunder Hukum Pidana Dalam Penanggulangan Tindak Pidana Perpajakan," Jurnal Penelitian Hukum De Jure 20, no. 02 (2020), https://doi.org/http://dx.doi.org/10.30641/dejure.2020.V20.165-176. h.7

${ }^{6}$ Ferry Irawan Febriansyah and Halda Septiana Purwinarto, "Pertanggungjawaban Pidana Bagi Pelaku Ujaran Kebencian Di Media Sosial," Jurnal De Jure 20, no. 2 (2020): 177-88. H.5
} 
aliran dualisme memisahkan antara tindak pidana dengan pertanggungjawaban pidana.

Konsep pertanggungjawaban pidana dalam KUHP saat ini cenderung lebih dekat dengan aliran monisme. Seolah-olah tindak pidana meliputi unsur obyektif dari suatu perbuatan yang menyatu pada unsur subyektif yang melekat pada si pelaku delik. Antara perbuatan dan pembuatnya disatukan. Dengan demikian, dalil penganut monisme, jika ada tindak pidana sudah pasti pelakunya dapat dipidana. Pemikiran konsep pertanggungjawaban pidana yang demikian menjadi konsen dari pembaruan hukum pidana di dalam RUU KUHP.

Selanjutnya, yang terpenting dari ketiga pilar hukum pidana tersebut ialah mengenai pemidanaan. KUHP peninggalan Belanda tidak memiliki pola pemidanaan yang begitu jelas. Terlebih lagi, tujuan pemidanaan yang dikandungnya hanyalah pembalasan. Pencelaan sanksi pidana bukan bertujuan memperbaiki pelaku melainkan efek jera dengan menestapakan pelaku oleh karena perbuatan jahatnya.

Pembaruan terhadap pilar hukum pidana dalam RUU KUHP merupakan masalah utama atau pokok yang akan sangat berpengaruh terhadap visi hukum pidana nasional di masa mendatang. Belum begitu banyak peneliti di bidang hukum pidana, fokus menuliskan topik arah baru pilar hukum pidana tersebut yang pada hubungannya dengan tindak pidana, pertanggungjawaban pidana, serta pemidanaan.

Topik yang sering diteliti dan dituliskan biasanya mengulas beberapa norma di dalam RUU KUHP dan kemudian dibandingkan dengan KUHP yang masih berlaku saat ini. Sebut saja, misalnya Rocky Marbun meneliti mengenai diskurusus perumusan ideologi sebagai perbuatan pidana dalam RUU KUHP. Negara masih memandang perlu melakukan pelarangan terhadap penyebaran ideologi komunisme, marxisme, dan leninisme. Rocky menemukan ketidakjelasan dan ketidaktegasan dalam membedakan sebagai hasil olah akal budi yang hasilkan ilmu pengetahuan dengan perbuatan sebagai delik yang diatur dalam RUU KUHP.7 Delik ideologi terlarang yang diatur dalam RUU KUHP, hal yang paling mendasar dari penelitian Rocky tidak terlepas dari kajian perbuatan (tindak pidana) dan kesalahan (pertanggungjawaban pidana). Dua hal kajian tersebut merupakan konsen dari penelitian penulis.

Penelitian Tody Sasmitha Jiwa Utama mengambil tema eksistensi hukum yang hidup (hukum adat) sebagai sumber hukum pemidanaan dan memperluas pemaknaan asas legalitas. Dalam temuannya, Tody menyimpulkan RUU KUHP memformulasikan hukum yang hidup sebagai dasar pemidanaan, di sisi lain mengabaikan hukum yang hidup sebagai dasar pengurangan pidana atau membebaskan seseorang dari pidana. Hal yang demikian, akan timbulkan resiko kesewenang-wenangan negara dan melahirkan dualitas hukum adat. 8 Sementara itu, orientasi topik yang penulis teliti mengulas asas legalitas hanya pada cakupan pada pilar tindak pidana, pada bagian penting lainnya yaitu pilar pertanggungjawaban pidana serta pemidanaan. Dua pilar yang paling akhir tidak menjadi fokus penelitian Tody.

\footnotetext{
${ }^{7}$ Rocky Marbun, "Grand Design Politik Hukum Pidana Dan Sistem Hukum Pidana Indonesia Berdasarkan Pancasila Dan Undang-Undang Dasar Negara Republik Indonesia 1945," Padjadjaran Journal of Law 1, no. 3 (2014). h. 1

${ }^{8}$ Tody Sas mitha Jiwa Utama, “'HUKUM YANG HIDUP'DALAM RANCANGAN KITAB UNDANGUNDANG HUKUM PIDANA (KUHP): ANTARA AKOMODASI DAN NEGASI," MasalahMasalah Hukum 49, no. 1 (2020): 14-25. h. 1
} 
Tulisan dari Adiansyah Nurahman dan Eko Soponyono, memiliki relevansi dengan penelitian dari penulis apabila dilihat dari konsep atau ide dasar yang melatarbelakangi lahirnya RUU KUHP. Meskipun demikian, fokus penelitian dari Adiansyah hanya berhenti pada asas keseimbangan Pancasila yang menjadi ide pembaharuan dalam hukum pidana. Mengingat KUHP masih berorientasi pada nilainilai kolonial. ${ }^{9}$ Sementara itu, penulis mengusung ide dasar keseimbangan menjadi fokus kajian sekaligus juga menguraikan arah baru pilar hukum pidana dalam RUU KUHP.

Berdasarkan pada uraian di atas, urgensi dalam penelitian ini akan menguraikan secara analitis mengenai dua hal fokus kajian persoalan; pertama, apakah ide dasar yang menjadi kerangka berfikir dalam pembaruan RUU KUHP. Ide dasar di sini dipahami sebagai pondasi yang menjadi dasar dari filsafat pembaruan RUU KUHP. Ide dasar juga bisa diasumsikan sebagai nilai dasar yang melandasi cita hukum KUHP di masa mendatang.

Persoalan kedua, bagaimana konkritisasi formulasi norma pembaruan pilar hukum pidana yang ada di dalam RUU KUHP. Sebagaimana yang diketahui dalam KUHP saat ini, tiga pilar hukum pidana (tindak pidana, pertanggungjawaban pidana, dan pemidanaan) apabila dilihat dari segi formulasi tidak begitu jelas dan relevan dengan perkembangan situasi kehidupan yang berkembang. Penguraian terhadap hal ini akan diulas pada bagian pembahasan nanti. Tujuan dari penelitian ini ialah untuk mengetahui arah baru pilar hukum pidana (trias pidana) dalam hal pembaruan hukum pidana melalui kebijakan politik hukum pidana. Selain itu, manfaat yang diperoleh dapat memberikan pengayaan pengembangan keilmuan hukum pidana utamanya bagi akademisi, sedangkan bagi praktisi hukum akan memberikan manfaat sebagai wawasan dalam penerapan hukum pidana di masa mendatang berbasis pada arah baru ide dasar dan kajian utama hukum pidana dalam RUU KUHP

\section{Metode Penelitian}

Metode penelitian yang digunakan yaitu penelitian hukum normatif. Oleh karena itu dalam penelitian hukum normatif terdiri dari bahan hukum primer dan bahan hukum sekunder serta bahan hukum tersier. Sumber literatur diperoleh dari kepustakaan serta dokumen dari bahan hukum primer dan bahan hukum sekunder. Bahan hukum primer seperti KUHP dan RUU KUHP. Selain itu, bahan hukum sekunder diperoleh dari literatur pustaka, jurnal, buku, dan hasil penelitian.

Pendekatan Penelitian yang digunakan dalam penelitian ini adalah metode Pendekatan konseptual (conceptual approach) dan Pendekatan Perundang-undangan (Statue Approach). Pendekatan ini dilakukan dengan melihat pandangan-pandangan dan doktrin-doktrin yang berkembang dalam ilmu hukum yang bertujuan untuk menemukan ide yang melahirkan konsep-konsep hukum, pengertian hukum, dan asas-asas hukum yang relevan dengan isu hukum. Teknik penelusuran bahan hukum dilakukan dengan metode studi dokumen atau penelitian kepustakaan (library research), yaitu pengumpulan bahan hukum dengan melakukan penelitian di perpustakaan terhadap sejumlah literatur, dokumen, pendapat pakar, serta artikel

\footnotetext{
${ }^{9}$ Adiansyah Nurahman and Eko Soponyono, "Asas Keseimbangan Dalam Rancangan Kitab UndangUndang Hukum Pidana Sebagai Upaya Pembaharuan Hukum Pidana Yang Berkeadilan," Pandecta Research Law Joumal 14, no. 2 (2019): 100-106. h. 05
} 
yang dapat menjelaskan konsep-konsep hukum. Teknik analisis bahan hukum yang digunakan adalah Diskiptrif analisis yang mengacu pada suatu masalah tertentu yang kemudian dikaitkan dengan literatur, pendapat pakar hukum, maupun berdasarkan peraturan perundang-undangan yang berlaku. ${ }^{10}$

\section{Hasil dan Pembahasan}

\subsection{Ide Dasar Pembaruan RUU KUHP}

Salah satu dari sekian pakar hukum pidana Indonesia yang identik dengan pembaruan hukum pidana ialah Barda Nawawi Arief. Barda merupakan representasi akademisi ahli di bidang hukum pidana yang dipercaya membahas dan mengkaji pembaruan RUU KUHP. Berbagai konsep RUU KUHP tidak terlepas peran diaspora pemikirannya.

Muhammad Rustamaji dalam artikel tulisannya, menuliskan secara khusus mengenai tema pemikiran hukum biomijuridika dari Barda Nawawi Arief. Bahkan Rustamaji menyatakan keterlibatan Barda dalam upaya pembaruan hukum pidana di Indonesia bisa jadi yang menyebabkan nama Barda menjadi sangat populer bagi penstudi hukum khususnya bidang pidana. Konsep biomijuridika sejatinya sebuah refleksi pemikiran dari Barda mengenai pembaruan hukum pidana Indonesia berdasarkan pada ajaran Ketuhanan. Hukum pidana Indonesia haruslah kembali pada jati diri Pancasila. KUHP (WvS) peninggalan Belanda terang begitu individualistik dan sekuler. Dalam konteks Indonesia, biomijuridika dari Barda sesungguhnya sejalan dengan Pancasila dan merupakan nilai yang mendasari ide dasar keseimbangan. ${ }^{11}$

RUU KUHP menurut Barda Nawawi Arief merupakan sebuah rancang bangun dari sistem hukum pidana Indonesia yang dimaksudkan untuk membangun dan memperbarui sebuah sistem baru. Makna pembaruan disini tidak dapat dikecilkan hanya sekedar terjebak dalam pembahasan perumusan pasal demi pasal semata. Pembaruan RUU KUHP hakikatnya adalah memperbarui konsep atau pokok pemikiran dan ide dasarnya, bukan sekedar urusan mengganti tambal sulam pasal secara tekstual. ${ }^{12}$

Ide dasar dalam pandangan Sholehuddin merupakan keyakinan yang menentukan cara pandang atas suatu fenomena. Berfungsi sebagai the central cognitive resource dalam menentukan rasionalitas dalam menjelaskan dan cara melihat suatu fenomena. Ide dasar sebagai gagasan bersifat mendasar lebih menyerupai cita hukum (rechtsidee) yang mengarahkan cita-cita yang diyakini dan diinginkan. Ide dasar sebagaimana apa yang diungkapkan oleh Rudolf Stamler sebagai leitstern (bintang pemandu), Oppenheimer menyebut sebagai (staatsidee) hakikat yang paling dalam dari Negara dalam menentukan bentuk dariNegara. ${ }^{13}$

\footnotetext{
${ }^{10}$ Mufatikhatul Farikhah, "Konsep Judicial Pardon (Pemaafan Hakim) Dalam Masyarakat Adat Di Indonesia," Jurnal Media Hukum 25, no. 1 (2016): 81-92.

${ }^{11}$ Muhammad Rustamaji, "Biomijuridika: Pemikiran Ilmu Hukum Pidana Berketuhanan Dari Barda Nawawi Arief," Undang: Jurnal Hukum 2, no. 1 (2019): 193-223. h. 02

${ }^{12}$ Barda Nawawi Arief, RUU KUHP Baru Sebuah Restrukturisasi/Rekonstruksi Sistem Hukum Pidana Indonesia (Semarang: Badan Penerbit Universitas Diponegoro, 2012). h. 33

${ }^{13}$ Sholehuddin, Sistem Sanksi Dalam Hukum Pidana Ide Dasar Double Track System Dan Implementasinya (Jakarta: Rajawali Press, 2003). h. 23-24
} 
Ide dasar dalam pembaruan hukum pidana akan sangat berpengaruh terhadap proses penegakan hukum pidana. Apabila dilihat dari sudut fungsional maka akan berorientasi pada fungsionalisasi bagaimana hukum pidana itu ditegakkan. Sebaliknya, jika dilihat dari sudut norma subtantif menitikberatkan pada keseluruhan sistem aturan norma hukum pidana materiil.

Dengan demikian, ide dasar tadi akan sangat mempengaruhi dinamika penegakan hukum pidana dalam arti penegak hukum mengimplementasikan norma hukum pidana di dalam kehidupan sehari-hari. KUHP saat ini, tidak mendasarkan dirinya pada ide dasar apa yang menjadi cita hukum bangsa Indonesia. Maka tidaklah heran, apabila penegakan hukum di masyarakat melahirkan paradoks di sana sini. Adagium masyarakat awam membahasakannya, hukum pidana tajam ke bawah (masyarakat kecil) tumpul ke atas (kalangan elit yang berkuasa atau pengusaha).

Krismiyarsi ketika menulis mengenai paradoks pandangan hukum positivistik dan progresif terhadap penegakan hukum pidana di Indonesia, ia mengatakan seringkali terjadi yang disebutkan dalam Undang-Undang tidak sejalan dengan rasa keadilan masyarakat. Aparat penegak hukum khususnya para hakim berpegang teguh pada teks hukum sehingga lebih sebagai juru bicara hukum. Contohnya kasus Mbok Minah yang mencuri 3 buah kakao milik perusahaan perkebunan PT Rumpun Sari Antan IV. Fakta ini tentu saja kontradiktif dan ironis dibandingkan kasus Ayin yang berada di penjara dengan "kamar mewah", dan berbeda dengan kasus Subandrio yang merupakan terpidana seumur hidup kasus gerakan 30 September yang mendapat remisi keluar dari penjara sebelum hukuman selesai. Setiap kasus memiliki "keistimewaan" dari sudut pandang positivisme dan hukum progresif. ${ }^{14}$

Ironi dan paradoks penegakan hukum pidana yang dituliskan oleh Krismiyarsi di atas merupakan satu dari sekian contoh yang terjadi. Boleh jadi hal ini disebabkan nilai yang dikandung oleh KUHP $(W v S)$ dapat membelenggu perilaku penegak hukum untuk lebih mengedepankan kepastian hukum ketimbang nilai keadilan. Prinsipnya, apabila penegakan hukum pidana dilihat dari asas legalitas Pasal 1 KUHP, apabila suatu perbuatan memenuhi unsur rumusan delik maka pasti pidana atau dapat dipidana, seolah-olah secara subtansi asas yang dikandung dalam Pasal 1 KUHP tersebut adalah "asas tiada maaf bagimu". Apakah benar nilai dan wawasan nasional bangsa Indonesia demikian? sebagaimana ilustrasi contoh kasus Mbok Minah yang hanya mencuri 3 buah kakao lalu dipidana. Apabila dilihat dalam nilai yang hidup dalam masyarakat Jawa adanya kesepakatan tidak tertulis terutama di Pedesaaan bahwa mengambil sisa panen (gresek/ngasak) bukan pencurian. Ekspresi nilai keadilan dan kemanfaatan lebih tampak ketimbang melihat formulasi dalam Pasal 1 KUHP. Perbuatan pidana hanya dilihat semata-mata pada dimensi rumusan delik. Karena untuk menyatakan suatu perbuatan dapat dipidana atau tidak sesuai dengan asas legalitas formal. Tanpa mau melihat kenyataan hukum yang hidup di masyarakat.

Meskipun Budi Suhariyanto mengakui terdapat kelemahan formulasi dalam mengakomodasi hukum pidana adat ketika dihubungkan dengan frasa dalam RUU KUHP yaitu hukum yang hidup, akan tetapi Budi mengakui bahwa sudah seharusnya

\footnotetext{
${ }^{14}$ Krismiyarsi Krismiyarsi, "The Paradox of Positivistic View and Progressive Law of Criminal Law Enforcement in Indones ia," Jurnal Media Hukum 20, no. 2 (2013). h. 02
} 
praktik penyerapan hukum adat oleh pengadilan selama ini dijadikan sebagai acuan dalam mengadakan pembaruan hukum pidana nasional. 15

KUHP tidak memberi ruang pada penggalian hukum yang hidup di masyarakat. Padahal, jauh sebelum hukum belanda masuk, eksistensi hukum adat dan hukum agama merupakan hukum yang hidup di masyarakat. Menjadi pertanyaan, apakah nilai yang dikandung di dalam KUHP (WvS) sudah sejalan dengan apa yang di citacitakan oleh bangsa yang merdeka dan berlandaskan pada Pancasila. Sementara yang diketahui, Pancasila memiliki nilai keseimbangan antara nilai Ketuhanan, Kemanusiaan, Kebangsaan, Demokrasi, dan Keadilan Sosial. Inilah ide dasar yang melandasi pembaruan hukum pidana Indonesia utamanya RUU KUHP.

Hukum pidana, apabila ingin disebut sebagai ilmu yang dapat menangkap dan mengikuti perubahan dan tidak mengabaikan nilai di dalam 'ruang publik', maka harus merefleksikan 'kehendak umum', dan 'sistem nilai' yang berada pada kriteria ide keseimbangan. Barda Nawawi Arief menyebut ide keseimbangan sebagai ide dasar yang ingin diwujudkan dalam konsep (RUU KUHP) berorientasi pada "ide/asas keseimbangan", yang antara lain mencakup:16

1. Ide keseimbangan monodualistik antara kepentingan masyarakat dan kepentingan individu

2. Ide keseimbangan antara "social welfare" dengan "scial defence"

3. Ide keseimbangan yang berorientasi pada pelaku/ "offender" (individualisasi pidana) dan "victim" (korban)

4. Ide keseimbangan antara "kepastian hukum" dan elastisitas/fleksibilitas, dan "keadilan"

5. Keseimbangan antara kriteria "formal" dan "materiil"

6. Keseimbangan nilai-nilai nasional dan nilai-nilai global/ internasional/ universal.

Ide keseimbangan monodualistik menghendaki adanya keseimbangan bahwa hukum pidana di satu sisi melindungi kepentingan umum (masyarakat) serta di sisi lain juga melindungi kepentingan individu. Sehingga, kehadiran hukum pidana melalui RUU KUHP memberikan perlindungan masyarakat (social defence) dengan memberikan sanksi dan larangan agar terjadi tertib sosial yang berpotensi tercapainya kesejahteraan masyarakat (social welfare). Penindakan terhadap pelaku (offender) tetap diperlukan dengan mempertimbangkan posisi korban (victim) hingga memperhatikan pemulihan korban. Keseimbangan antara nilai kepastian dan keadilan dalam RUU KUHP ditempatkan secara proporsional sesuai dengan konteks dan situasinya. Kata kunci dari itu adalah RUU KUHP lebih fleksibilitas dan elastis, misalnya dalam pedoman pemidanaan meskipun sanksi pidana dirumuskan secara alternative, namun hakim dapat menjatuhkan sanksi pidana secara kumulatif. Ide keseimbangan yang paling tampak dalam RUU KUHP adalah dinamisasi antara kriteria "formal" dan "materiil". Sebagaimana secara seimbang menempatkan asas legalitas formiil (hukum tertulis) dan asas legalitas materiil (hukum yang hidup) dalam RUU KUHP.

\footnotetext{
${ }^{15}$ Budi Suhariyanto, "Kedudukan Perdamaian Sebagai Penghapus Pemidanaan Guna Mewujudkan Keadilan Dalam Pembanuan Hukum Pidana," Jurnal Rechts Vinding: Media Pembinaan Hukum Nasional 6, no. 1 (2017): 1-19. h. 14

${ }^{16}$ Barda Nawawi Arief, Perkembangan Asas-Asas Hukum Pidana Indonesia (Perspektif Perbandingan Hukum Pidana), ed. Badan Penerbit Universitas Diponegoro (Semarang, 2012). h. 24
} 
Ide atau asas keseimbangan yang diwujudkan dalam RUU KUHP sebagaimana yang telah diuraikan di atas, merupakan arah baru dari pembaruan hukum pidana nasional termasuk pula RUU KUHP yang terinspirasi dari ide dasar nilai keseimbangan Pancasila yaitu nilai Ketuhanan, nilai Kemanusiaan, dan nilai Kemasyarakatan.

\subsection{Pembaruan Pilar Hukum Pidana (Trias Pidana) dalam RUU KUHP}

Trias pidana dalam kajian ilmu hukum pidana tidak begitu populer. Berbeda seperti halnya trias politica yang mendapatkan tempat kajian tidak serius pada bidang hukum tata negara. Kendati demikian, beberapa penstudi hukum pidana di Indonesia, salah satunya Barda Nawawi Arief17 telah memperkenalkan istilah trias hukum pidana.

Trias Politica merupakan sebuah konsep yang disampaikan oleh filsuf ternama asal Perancis yaitu Montesquieu. Sebuah konsep pembagian serta pemisahan kekuasaan dalam istilah Yunani Tri, artinya tiga, dan As mengandung makna pusat atau poros, sementara Politica menjelaskan mengenai kuasa atau kekuasaan. Operasionalisasi dari trias politica yaitu dalam suatu kekuasaan negara adanya pembagian kekuasaan yaitu legislatif, eksekutif, dan yudikatif. Kuasa legislasi membuat undang-undang, kuasa eksekutif pelaksana peraturan, dan kuasa yudikatif ialah mengadili atas dasar undangundang. 18

Naskah akademik RUU KUHP menyajikan tiga masalah pokok hukum pidana yaitu tindak pidana (strafbaarfeit/criminal act/actus reus), kesalahan (schuld/guilt/mens rea), dan pemidanaan (straf/punishment/poena) merupakan tiga pilar pembaharuan hukum pidana dalam RUU KUHP. Adalah Sauer yang mempopulerkan istilah trias hukum pidana yaitu sifat melawan hukum (unrecht), kesalahan (schuld), dan pidana (strafe). Packer menyebutnya sebagai the three concept atau the three basic problems yaitu offence, guilt, dan punishment. ${ }^{19}$ Dalam istilah Saner disebut sebagai onrecht, schuld, dan strafe.

Faisal menjelaskan di dalam bukunya, bahwa ketiga pilar hukum pidana (trias pidana) yang telah disampaikan Barda, Muladi, dan Chairul Huda ketika merujuk para ahli pidana tersebut sejatinya hal ini adalah bagian penting dari rekonstruksi sistem hukum pidana nasional. ${ }^{20}$

Perhatian utama dari pilar tindak pidana ialah pada perbuatan. Prihal apa yang menjadi dasar dalam hal menetapkan sebuah perbuatan dikatakan sebagai delik. Dua istilah penting dalam kajian hukum pidana ketika berbicara mengenai perbuatan yaitu mala in se dan mala prohibita. Kedua istilah ini secara konsepsional memiliki arti yang berbeda. Suatu perbuatan yang secara hakiki memiliki sifat jahat tanpa harus diatur oleh Undang-Undang disebut sebagai mala in se, misalnya mencuri dan membunuh pada prinsipnya merupakan perbuatan tercela. Sebaliknya sesuatu perbuatan yang

\footnotetext{
${ }^{17}$ Arief, Kebijakan Hukum Pidana Perkembangan Penyusunan Konsep KUHP Baru.h. 79

${ }^{18}$ Efi Yulistyowati, Endah Pujiastuti, and Tri Mulyani, "Penerapan Konsep TRIAS POLITICA Dalam Sistem Pemerintahan Republik Indonesia: Studi Komparatif Atas Undang-Undang Dasar Tahun 1945 Sebelum Dan Sesudah Amandemen," Jumal Dinamika Sosial Budaya 18, no. 2 (August 9, 2017): 32838, https ://doi.org/10.26623/JDSB.V18I2.580.

${ }^{19}$ Draf Naskah Akademik Rancangan Undang-Undang Tentang Kitab Undang-Undang Hukum Pidana (KUHP), (2015). Jakarta: BPHN Kemenkumham RI, p.19

${ }^{20}$ A Faisal, "Membangun Politik Hukum Asas Legalitas Dalam Sistem Hukum Pidana Indonesia," Ius Quia Iustum Law Journal 21, no. 1 (n.d.): 81-95.
} 
dikatakan tercela karena dinyatakan oleh Undang-Undang, misalnya pelanggaran lalu lintas dapat disebut sebagai mala prohibita.

Pilar peratanggungjawaban pidana konsen pada unsur kesalahan. Tiada pidana tanpa kesalahan merupakan dalil pembaruan yang diusung dalam RUU KUHP. Menurut Roeslan Saleh sebagaimana yang dikutip oleh Silvia Kurnia Dewi, ada dua unsur penting dalam pilar pertanggungjawaban pidana yaitu perbuatan pidana dan kesalahan. Perbuatan pidana mendahului pertanggungjawaban pidana. Artinya seseorang tidak mungkin bisa bertanggung jawab tanpa terlebih dahulu melakukan perbuatan pidana. Bahkan tidak adil rasanya seseorang harus bertanggungjawab sedangkan seseorang tersebut tidak melakukan perbuatan yang dituduhkan. Selain unsur perbuatan pidana, unsur lain dalam pertanggungjawaban pidana ialah unsur kesalahan. Hal ini senada dengan asas tiada pidana tanpa kesalahan (geen straf zonder schuld) atau (keine Strafe ohne Schuld) atau (actus non facit reum nisi mens sir rea). Kesalahan merupakan aspek penting di sini untuk melihat hubungan perbuatan dengan rumusan delik, serta hubungan perbuatan dengan sikap batin (niat) dari si pelaku. Adanya konsep pemisahan antara pertanggungjawaban pidana dengan

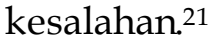

Berikutnya pilar pemidanaan berhubungan dengan sanksi pidana serta tujuan dari pemidanaan. Yaris Adhial Fajrin dengan merujuk pendapat Muladi, bahwa pada era modern saat ini, sanksi pidana semakin manusiawi dan cenderung dalam penerapan mencari sisi manfaat dalam rangka resosialisasi pelaku kejahatan. Sanksi pidana berupa perampasan kemerdekaan yang semakin tidak populer dan ketinggalan zaman, mulai beralih ke sanksi tindakan dan rehabilitasi agar lebih manusiawi. Hukuman terhadap kejahatan semakin manusiawi selama munculnya aliran neoklasik, sehingga mengingatkan para peneliti pada gagasan individualisasi kehajatan. Sistem pidana saat ini dalam hukum pidana modern berorientasi pada pelaku dan perbuatan (Daad-Dader Straafrecht) sehingga jenis sanksi yang dijatuhkan tidak hanya mencakup sanksi pidana tetapi juga sanksi tindakan.22

Pilar-pilar yang diuraikan di atas merupakan kajian fundamental hukum pidana yang mana Sauer menegaskan sebagai trias hukum pidana. Berangkat dari permasalah pokok dari trias hukum pidana, maka usaha pembaruan tidak akan kehilangan visi dan rancang bangun yang menjadi arah baru RUU KUHP. Seperti yang telah dikemukakan, bahwa trias hukum pidana merupakan fokus kajian dalam membangun grand design sistem hukum pidana nasional. Visi dan rancang bangun arah baru RUU KUHP sudah semestinya berbasis pada nilai keseimbangan Pancasila sebagai sumber dari sistem hukum nasional. Betapa penting visi ini dibangun, mengingat KUHP peninggalan Belanda nilai dasar yang dibangun tidak kompatibel dengan nilai keseimbangan Pancasila dan wawasan nasional.

Grand design diperlukan dalam rangka untuk melakukan sinkronisasi dan harmonisasi agar bergeraknya hukum sebagai sarana memiliki fungsi sebagai wujud dari pembentukan sistem hukum dalam mencapai tujuan-tujuan hukum yang telah

\footnotetext{
${ }^{21}$ Silvia Kurnia Dewi, "Perumusan Pertanggungjawaban Tindak Pidana Korporasi Dalam Berbagai Undang-Undang," Arena Hukum 13, no. 1 (2020): 135-56.

${ }^{22}$ Yaris Adhial Fajrin, "Reconstruction of Castration Sanction Formulation in The Perspective of Indones ian Criminal Law Renewal,” Jurnal Dinamika Hukum 19, no. 2 (2019): 389-406.
} 
disepakati secara bersama. ${ }^{23}$ Grand design yang diperlukan saat ini adalah melakukan konsolidasi terhadap dua hal; pertama, pemetaan terhadap nilai yang hidup dan wawasan nasional yang akan diadaptasikan dalam RUU KUHP. Kedua, sinkronisasi dan harmonisasi RUU KUHP dan peraturan pidana lainnya.

Sebagaimana yang telah dikemukakan pada bagian sebelumnya, pembaruan pilar hukum pidana akan fokus pada permasalahan utama dalam hukum pidana, yakni tindak pidana (perbuatan), pertanggungjawaban pidana (kesalahan), dan pemidanaan (sanksi pidana). Ketiga hal ini merupakan pilar penting yang disebut juga sebagai trias pidana dalam pembaruan RUU KUHP.

Pilar pertama mengenai tindak pidana yang hubungannya pada unsur perbuatan, akan menyajikan ulasan mengenai dua hal, yaitu apakah dalil dan dasar untuk menyatakan suatu tindak pidana, dan adakah definisi yuridis mengenai tindak pidana.

Pasal 1 ayat (1) KUHP sering kali dipahami dalam ilmu hukum pidana sebagai wujud penormaan dari asas legalitas. Bahkan sering pula, dikenali sebagai pengertian normatif dari tindak pidana. Untuk menetapkan suatu perbuatan diliputi delik apa tidak, maka sumber hukum dasar patut dipidananya suatu perbuatan selalu berdasarkan pada ketentuan perundang-undangan secara tertulis. Sejalan dengan asas legalitas formal yang merupakan hakikat dari Pasal 1 ayat (1) KUHP.

Marthen H. Toelle mengatakan suatu perbuatan dapat dikualifikasi sebagai tindak pidana ketika negara memberikan justifikasi kriminalisasi atas perbuatan tersebut dalam peraturan perundang-undangan. Moeljatno sendiri menguraikan dilarang dan diancamnya suatu perbuatan dasar pokoknya ada pada asas legalitas (principle of legality). Asas ini menentukan bahwa tidak ada suatu perbuatan dilarang dan diancam dengan pidana jika tidak ditentukan sebelumnya terlebih dahulu dalam undangundang. Dalam istilah dikenal nullum delictum nulla poena sine praevia lege poenali yaitu tidak ada delik, tidak ada pidana tanpa peraturan terlebih dahulu. ${ }^{24}$

Faisal dalam tulisannya menuding bahwa asas legalitas dalam KUHP hanya menganut ajaran sifat melawan hukum formiil. Titik tekan untuk dikatakan tindak pidana apabila suatu perbuatan telah memenuhi unsur delik. Delik merupakan apa yang telah dituliskan dan dinyatakan dalam Undang-Undang. Tidak ada tempat dan ruang untuk hukum tidak tertulis. Kerangka pikir yang dianut ialah nilai individualism dan liberalism. Hakikat asas legalitas formiil KUHP tidak berangkat dari kultur bangsa Indonesia yang pemaaf, toleran, plural, kekeluargaan, bernurani, religius atau yang lebih berarti adalah jiwa Pancasila. Nilai individualistik hanya bisa menawarkan asas kepastian hukum dengan melanggengkan rasionalitas teks secara tertulis menjadi domain utama dalam menentukan salah-benar suatu perbuatan. Artinya hanya hukum pidana tertulis yang dapat menentukan mana perbuatan jahat dan tidak jahat. ${ }^{25}$

Kritik tajam terhadap asas legalitas diajukan oleh Fransiskus Saverius Nurdin. Asas legalitas merupakan manifestasi sisi negatif dari hukum itu sendiri. Asas Legalitas tidak pada posisi sebagai bagian dari hukum yang sebenarnya (sisi positif) di mana hukum bukanlah sekedar perkara undang-undang atau daftar peraturan melainkan

\footnotetext{
${ }^{23}$ Marbun, "Grand Design Politik Hukum Pidana Dan Sistem Hukum Pidana Indonesia Berdasarkan Pancasila Dan Undang-Undang Das ar Negara Republik Indones ia 1945."

${ }^{24}$ Marthen H Toelle, "Kriminalisasi Ditinjau Dari Perspektif Teori Hukum Pidana (Criminal Law Theory)," Refleksi Hukum: Jumal Ilmu Hukum 8, no. 2 (2014): 115-32.

${ }^{25}$ Faisal, "Membangun Politik Hukum Asas Legalitas Dalam Sis tem Hukum Pidana Indonesia."
} 
sesuatu yang tertanam pada jiwa manusia, sesuatu yang merupakan bagian integral dari pengalaman manusia. Asas legalitas lahir sebagai klimaks perjuangan manusia yang menghendaki adanya hukum pidana yang tertulis dalam bentuk undangundang, untuk membatasi kesewenangan penguasa dan hakim yang menetapkan hukum menurut perasaan mereka sendiri.26

Pembaruan hukum pidana tidak mungkin dapat dilepaskan dari sistem hukum nasional dalam mencapai tujuan bernegara. Sumber dari sistem hukum nasional ialah Pancasila. Lantas, apakah asas kepastian hukum sebagaimana yang menjiwai asas legalitas formal dalam KUHP merupakan asas tunggal dalam negara hukum yang berlandaskan Pancasila. Sudah barang tentu pemahaman yang demikian tidak dapat dibenarkan.

Indonesia, sebagai negara yang berdasarkan atas hukum sebagaimana yang termuat dalam Konstitusi Pasal 1 Ayat (3) serta Pancasila sebagai pijakan ideologi, tentu nilai nilai dan orientasi bernegara harus mampu memberikan perlindungan hukum, kepastian, keadilan dan kemanfaatan bagi seluruh rakyatnya agar apa yang termaktub dalam tujuan bernegara dapat tercapai. ${ }^{27}$

Tujuan bernegara melindungi segenap bangsa Indonesia serta tumpah darah Indonesia, memajukan kesejahteraan umum, mencerdaskan kehidupan bangsa serta ikut serta melaksanakan ketertiban dunia berlandaskan Pancasila. Jelas tujuan ini membutuhkan tata hukum yang diimplementasikan dalam pembaharuan hukum termasuk pembaharuan hukum pidana. Sebagaimana UU No. 1 Tahun 1945 tentang Peraturan Hukum Pidana, meskipun dalam perkembangannya telah diadakan perubahan, harus disesuaikan dengan kondisi dan suasana negara merdeka serta kebutuhan praktis di lapangan.28

Dengan demikian, tujuan bernegara tidak saja dipandu oleh asas kepastian hukum, disitu juga terdapat hal penting lainnya yaitu keadilan dan kemanfaatan. Apakah untuk mencari dan menggali nilai keadilan dan kemanfaatan hanya ada di dalam Undang-Undang seperti apa yang disebutkan di dalam asas legalitas formiil tersebut. Padahal hukum yang hidup (hukum tidak tertulis) di beberapa tempat dapat memberikan kemanfaatan bahkan menjaga keseimbangan sosial masyarakat. Dengan adanya Pasal 1 ayat (1) KUHP, hukum tidak tertulis tidak dapat menjadi sumber hukum pemidanaan.

Pada Seminar Hukum Nasional Maret 1963, menghasilkan resolusi penting yang berhubungan dengan bidang hukum pidana bahkan menyebutkan asas legalitas. Moeljatno menegaskan hal ini di dalam bukunya. Kiranya perlu mengajukan garisgaris pokok apakah yang diputuskan dalam bidang hukum pidana, salah satunya ialah dalam KUHP Baru pada bagian umum (fundamentals), antara lain asas legalitas hendaknya disusun secara progresif sesuai dengan kepribadian Indonesia dan perkembangan Revolusi. ${ }^{29}$

\footnotetext{
${ }^{26}$ Fransiskus Saverius Nurdin, "Rekonstruksi Asas Legalitas Dalam Hukum Pidana Berdasarkan Prinsip Keadilan," Refleksi Hukum: Jurnal Ilти Hukum 1, no. 1 (2016): 1-14.

${ }^{27}$ Diding Rahmat, "Formulasi Kebijakan Pidana Denda Dan Uang Pengganti Dalam Penegakan Tindak Pidana Korupsi Di Indonesia," Jurnal IUS Kajian Hukum Dan Keadilan 8, no. 1 (2020): 79-88.

${ }^{28}$ Iskandar Wibawa, "Pidana Kerja Sosial Dan Restitusi Sebagai Alternatif Pidana Penjara Dalam Pembaharuan Hukum Pidana Indonesia," Jumal Media Hukum 24, no. 2 (2017): 105-14.

${ }^{29}$ Moeljatno, Fungsi Dan Tujuan Hukum Pidana Indonesia (PT. Bina Aksara, Jakarta, 1985). h. 11
} 
Adanya kehendak untuk merubah asas legalitas dalam pemikiran yang progresif adalah wujud dari wawasan nasional yang dipengaruhi oleh semangat proklamasi kemerdekaan, nasionalisme dan patriotisme. Semangat pembaruan hukum pidana, telah disadari jauh sebelum konsep RUU KUHP itu hadir. Bahwa Soekarno sebagai penggali asas-asas hukum nasional melalui spirit proklamasinya dan dilanjutkan kembali melahirkan ideologi Pancasila. Sehingga dinyatakan bahwa dalam usaha mengembangkan pembangunan hukum nasional termasuk hukum pidana haruslah menyesuaikan diri dengan perkembangan revolusi bangsa Indonesia yang merdeka.

Meskipun disadari, pembaruan hukum pidana tidak sebatas hanya pembaruan RUU KUHP. Pernyataan ini disampaikan oleh Marcus Priyo Guntaro, pembaruan yang menyeluruh tidak cukup dilakukan pembaruan KUHP. Pembaruan hukum pidana harus pula mencakup pembaruan bidang kultural (budaya), struktural (aparatur hukum), dan materi (subtansi hukum). Tidak akan member arti yang signifikan apabila pembaruan tersebut tidak disertai pembaruan ilmu hukum pidananya serta wawasan penegak hukumnya mengenai cara pandang mereka terhadap hukum dan keadilan. Bahkan Sudarto menyatakan hal yang sama jika pembaruan hukum pidana holistik terletak pada pembaruan hukum pidana materiil, hukum pidana formiil, dan hukum pelaksanaan pidana. ${ }^{30}$

Pembaruan RUU KUHP terkait pilar tindak pidana, pertanggungjawaban pidana dan pemidanaan hanya mencakup satu aspek saja yaitu pembaruan hukum pidana materiil saja. Kendati demikian, betapa penting pembaruan politik hukum asas legalitas dalam KUHP agar dapat memberikan perubahan terhadap budaya hukum dan struktur hukum dalam hal penegakan hukum pidana.

Demi kepentingan itu, diperlukan perluasan dalam memaknai asas legalitas dalam konteks pembaruan hukum pidana materiil. Sebagai sumber hukum dan dasar dapat dipidananya suatu perbuatan tidak hanya bersumber pada sumber hukum formiil melainkan pula pada sumber hukum materiil. Asas legalitas dalam RUU KUHP saat ini mengadopsi asas kepastian dalam pengertian asas legalitas formiil dan asas keadilan dalam arti asas legalitas materiil. Jadi, adanya keseimbangan sebagai ide dasar dalam melakukan pembaruan RUU KUHP.

RUU KUHP dengan memberi ruang terhadap hukum yang hidup sebagai dasar atau sumber hukum pemidanaan sebagai perluasan asas legalitas setidaknya dalil ini disokong oleh beberapa argumentasi, pertama bahwa adanya semangat pembaruan hukum yang diperoleh dari jiwa proklamasi yaitu nilai nasionalisme dan patriotisme. Kedua, adanya wawasan nasional yang dilahirkan di berbagai pertemuan seminar nasional. Ketiga, asas legalitas materiil tumbuh berkembang berdasarkan karakteristik sosiologis bangsa Indonesia. Keempat, adanya penelitian hukum adat yang dilakukan tim perumus dan pengkaji RUU KUHP. Kelima, dihasilkan dari kajian perbandingan hukum.

Dengan demikian, perubahan yang terjadi dalam RUU KUHP merupakan perluasan makna asas legalitas yang merepresentasikan dari ide keseimbangan. Sebagai sumber hukum dan dasar pemidanaan diformulasikan dalam bentuk norma RUU KUHP Pasal

\footnotetext{
${ }^{30}$ Marcus Priyo Gunarto, "Asas Keseimbangan Dalam Konsep Rancangan Undang-Undang Kitab Undang-Undang Hukum Pidana," Mimbar Hukum-Fakultas Hukum Universitas Gadjah Mada 24, no. 1 (2012): 83-97.
} 
1 ayat 1 merupakan sumber hukum tertulis, dan Pasal 2 ayat 1 sebagai seumber hukum tidak tertulis.

Perluasan makna asas legalitas formiil ke asas legalitas materiil berimplikasi pada pendefinisian tindak pidana. Setidaknya RUU KUHP telah memberikan terminologi yuridis terhadap tindak pidana. Pertama, tindak pidana ialah suatu perbuatan baik itu melakukan dalam arti pasif dan aktif yang oleh peraturan dinyatakan sebagai perbuatan dilarang dan diancam sanksi pidana. Kedua, perbuatan tersebut bersifat melawan hukum serta bertentangan dengan hukum yang hidup. Ketiga, pada prinsipnya tindak pidana bersifat melawan hukum kecuali ada alasan pembenar terhadapnya.

Asas legalitas formiil mendasarkan diri pada kepastian hukum. Sebagaimana pandangan Jan Michiel Otto kepastian hukum merupakan sicherkeit des rechts selbst, yaitu kepastian tentang aturan hukum itu sendiri. ${ }^{31}$ Berbeda dengan asas legalitas materiil mendasarkan diri pada kemanfaatan dan keadilan.

Pembaruan hukum pidana terhadap pilar tindak pidana pada intinya menyangkut sumber hukum dan dasar untuk menyatakan seuatu perbuatan dapat dipidana atau tidak berdasarkan pada asas legalitas formiil dan asas legalitas materiil. Perluasan makna asas legalitas tersebut memicu hadirnya definisi tindak pidana secara yuridis termaut dalam ketentuan RUU KUHP.

Selanjutnya, pembahasan mengenai pilar pertanggungjawaban pidana yang berhubungan erat dengan unsur kesalahan. Kebaruan yang nyata dalam RUU KUHP ialah asas tiada pidana tanpa kesalahan. Asas ini merupakan asas fundamental dalam kemampuan bertanggungjawab seorang pelaku. Pokok pemikiran yang mendasari ialah keseimbangan monodualistik yang salah satu cirinya fleksibelitas (tidak kaku), dalil pemidanaan tidak hanya karena tindak pidana (asas legalitas), dan implementasi dari nilai Pancasila.

Septa Candra menjelaskan konsep monodualistik (daad en dader strafrecht) dalam mengulas konsep pertanggungjawaban pidana. Proses wajar (due process) penentuan pertanggungjawaban pidana harus pula memperhatikan kepentingan masyarakat dan kepentingan si pelaku. Proses bergantung pada dapat dipenuhinya syarat dan keadaan dapat dicelanya pembuat tindak pidana, sehingga sah jika dijatuhi pidana. Menurut Galligan apabila persyaratan ini diabaikan dan tidak tampak keadaan kriminal yang menunjukkan pembuat dapat dicela maka hukum dan institusinya telah gagal memenuhi fungsinya. ${ }^{32}$

Keseimbangan monodualistik yang dimaksud ialah asas kesalahan (asas culpabilitas) yang merupakan asas kemanusiaan disandingkan dengan asas legalitas (principle of legality) yaitu asas kemasyarakatan. Dalil yang dibangun oleh asas geen straf zonder schuld (asas tiada pidana tanpa kesalahan) bahwa setiap orang tidak dapat dipidana kecuali adanya kesalahan pada perbuatannya. Konsekuensi dari asas ini ialah adanya pemisahan yang tegas antara tindak pidana dan pertanggungjawaban pidana. Arah

31 Faisal Faisal and Muhammad Rustamaji, "Perspektif Hukum Pidana Dalam Polemik Pengajuan Sumpah Advokat: Telaah Putusan Mahkamah Konstitusi Nomor 35/PUUXVII/ 2018 Atas Surat Ketua Mahkamah Agung RI Nomor 73/KMA/HK. 01/IX/2015," Jurnal Hukum Ius Quia Iustum 27, no. 3 (2020): 458-80.

${ }^{32}$ Septa Candra, "Pembaharuan Hukum Pidana; Konsep Pertanggungjawaban Pidana Dalam Hukum Pidana Nas ional Yang Akan Datang," Jumal Cita Hukum 1, no. 1 (2013): 95895. 
baru pertanggungjawaban pidana dalam RUU KUHP mengakomodasi asas tiada pidana tanpa kesalahan.

Pilar penting yang terakhir dalam pembaruan hukum pidana adalah pemidanaan. Pada era klasik hukum pidana hanya digunakan sebagai alat untuk mencapai tujuan pembalasan bagi pelaku. Sanksi pidana dipercaya dapat mengatasi akibat yang ditimbulkan dari kejahatan. Paham semacam ini bertahan cukup lama melalui teori retributif. Tidak ada celah untuk memperbaiki pelaku. Kesalahan pelaku merupakan ketercelaan moral yang pantas untuk diberikan efek jera dengan penestapaan. Tujuan pemidanaan semata-mata sebagai sarana membalas perbuatan.

KUHP Belanda sangat tertinggal jauh dengan perkembangan dan kebutuhan masyarakat. Khususnya mengenai pemidanaan, dirasa tidak sesuai dengan apa yang diharapkan masyarakat. Sistem pemidanaan dalam KUHP bersifat individualistic. Bahkan mengabaikan realitas nilai perdamaian sehingga tidak dijadikan sebagai dasar penghapusan pemidanaan. KUHP kurang mengakomodasi penerapan filosofi musyawarah mufakat berdasarkan Pancasila. Perdamaian sebagai asas penyelesaian konflik antar warga masyarakat baik yang bersifat individual maupun ketertiban umum. ${ }^{3}$

Berdasarkan atas hal itu, maka RUU KUHP memiliki tujuan pemidanaan sejalan dengan ide dasar keseimbangan perlindungan masyarakat dan perlindungan individu pelaku pidana. Perlindungan masyarakat tampak dalam formulasi RUU KUHP masih mempertahankan sanksi pidana mati dan pidana seumur hidup. Meskipun pidana mati masuk pada pidana pokok dan ditempatkan secara khusus bersifat eksepsional. Dimensi perlindungan individu pelaku kejahatan ketika mencantumkan penerapan pidana mati secara selektif dan juga terdapat penundaan pidana mati dengan masa percobaan selama sepuluh tahun hukuman.

Formulasi tujuan pemidanaan ditegaskan dalam RUU KUHP yaitu; pertama, pemidanaan sebagai sarana mencegah terjadinya tindak pidana demi pengayoman masyarakat. Kedua, membina terpidana dengan memasyarakatkan kembali sehingga adanya perbaikan perilaku. Ketiga, memperbaiki keadaan ke kondisi semula antara pihak korban dan pelaku dengan tujuan memulihkan keseimbangan dalam mendatangkan perdamaian. Keempat, membebaskan rasa bersalah pada terpidana. Kelima, pemidanaan tidak dimaksudkan untuk pembalasan yang merendahkan martabat manusia. Di samping itu pula, ada pedoman pemidanaan ketika hakim mengadili suatu perkara wajib lebih mengutamakan keadilan daripada kepastian hukum apabila adanya pertentangan antara kedua nilai tersebut.

Pembaruan pilar hukum pidana yang terfokus pada tindak pidana, pertanggungjawaban pidana, dan pemidanaan harus dilihat sebagai usaha dari dekolonialisasi terhadap KUHP peninggalan Belanda. Ide dasar yang hendak dibangun adalah nilai keseimbangan Pancasila yang tercermin dalam wawasan hukum nasional dan dituangkan dalam hasil pemikiran seminar hukum nasional. Pembaruan pilar hukum pidana RUU KUHP apabila dilihat sebagai bagian ilmu hukum pidana, maka keseimbangan antara aspek normatif dan nilai kemasyarakatan betapa penting diformulasikan dalam sebuah norma-norma RUU KUHP.

\footnotetext{
33 Suhariyanto, "Kedudukan Perdamaian Sebagai Penghapus Pemidanaan Guna Mewujudkan Keadilan Dalam Pembaruan Hukum Pidana."
} 
Desain konseptual yang dapat ditawarkan oleh penulis dalam memperkuat upaya pembaruan pilar hukum pidana (tindak pidana, pertanggungjawaban pidana, dan pemidanaan) bahwa dalam mereformulasi pembaruan pilar hukum pidana tersebut harus pula berorientasi pada kebijakan sosial dan kebijakan kriminal, berorientasi pada sistem hukum nasional, berorientasi pada perspektif keilmuan, dan berorientasi pada perbandingan hukum pidana.

\section{Kesimpulan}

Pembaruan hukum pidana sejatinya cukup luas, yaitu pembaruan hukum pidana materiil, hukum pidana formiil dan pembaruan pelaksanaan pidana. Orientasi pembaruan pilar hukum pidana dalam RUU KUHP hanya mencakup pembaruan hukum pidana materiil. Kerangka berfikir pembaruan pilar hukum pidana (tindak pidana, pertanggungjawaban pidana, dan pemidanaan) bertolak dari ide dasar keseimbangan yang dilandasi oleh nilai keseimbangan Pancasila yaitu nilai Ketuhanan, Kemanusiaan, dan Kemasyarakatan. Ide dasar keseimbangan tersebut diterjemahkan meliputi; pertama, keseimbangan monodualistik (harmoni kepentingan individu dan masyarakat) Kedua, keseimbangan perlindungan sosial dan tujuan kesejahteraan sosial. Ketiga, keseimbangan nilai kepastian hukum dan keadilan. Keempat, keseimbangan individualisasi pidana dan korban. Kelima, keseimbangan pada aspek formal dan materiel. Keenam, keseimbangan nilai nasional dan universal. Ide keseimbangan ini kemudian, menjadi dasar dalam merumuskan penormaan dalam RUU KUHP dan menjadi arah baru dari pembaruan pilar hukum pidana.

Pembaruan pilar hukum pidana dalam RUU KUHP diwujudkan melakukan pembaruan subtansif terhadap pilar tindak pidana bahwa untuk menyatakan suatu perbuatan dapat dipidana atau tidak bersumber pada asas legalitas formiil dan asas legalitas materiil. Adanya perluasan makna asas legalitas formiil menuju materiil berdampak pada hadirnya terminologi yuridis mengenai tindak pidana dalam RUU KUHP. Pilar pertanggungjawaban pidana mengakomodasi asas geen straf zonder schuld (asas tiada pidana tanpa kesalahan) merupakan arah baru dari pemisahan antara pertanggungjawaban pidana dengan tindak pidana. Sementara pilar pemidanaan telah memformulasikan secara tegas dalam RUU KUHP mengenai karakteristik dari tujuan pemidanaan tidak lagi semata-mata sebagai sarana pembalasan, akan tetapi adanya upaya meresosialisasikan pelaku kembali ke masyarakat. Perubahan mendasar pada ketiga pilar hukum pidana tersebut tidak terlepas dari ide dasar keseimbangan nilai Pancasila.

\section{Ucapan Terima Kasih}

Terima kasih kepada Fakultas Hukum Universitas Bangka Belitung yang telah mendukung penulis untuk selalu mempublikasikan hasil karya ilmiah ke jurnal nasional bereputasi sebagai wujud pengembangan penelitian. Peran Lembaga Penelitian dan Pengabdian Masyarakat Universitas Bangka Belitung juga turut andil dalam hal memberikan dukungan agar setiap dosen senantiasa berakselerasi melakukan penelitian yang dipublikasikan. 


\section{Daftar Pustaka}

Buku

Arief, Barda Nawawi. Kebijakan Hukum Pidana Perkembangan Penyusunan Konsep KUHP Baru. Jakarta: Kencana, 2011.

- - - . Kumpulan Hasil Seminar Hukum Nasional Ke I s/d VIII Dan Konvensi Hukum Nasional 2008 Tentang Undang-Undang Dasar 1945 Sebagai Landasan Konstitusional Grand Design Sistem Dan Politik Hukum Nasional. Semarang: Badan Penerbit Universitas Diponegoro, 2011.

- - - . Perkembangan Asas-Asas Hukum Pidana Indonesia (Perspektif Perbandingan Hukum Pidana). Edited by Badan Penerbit Universitas Diponegoro. Semarang, 2012.

- - . RUU KUHP Baru Sebuah Restrukturisasi/Rekonstruksi Sistem Hukum Pidana Indonesia. Semarang: Badan Penerbit Universitas Diponegoro, 2012.

Muladi, and Diah Sulistyani. Catatan Empat Dekade Perjuangan Turut Mengawal Terwujudnya KUHP Nasional (Bagian I, 1980-2020). Semarang: Universitas Semarang, 2020.

\section{Jurnal}

Candra, Septa. "Pembaharuan Hukum Pidana; Konsep Pertanggungjawaban Pidana Dalam Hukum Pidana Nasional Yang Akan Datang." Jurnal Cita Hukum 1, no. 1 (2013): 95895.

Dewi, Silvia Kurnia. "PERUMUSAN PERTANGGUNGJAWABAN TINDAK PIDANA KORPORASI DALAM BERBAGAI UNDANG-UNDANG." Arena Hukum 13, no. 1 (2020): 135-56.

Faisal, A. "Membangun Politik Hukum Asas Legalitas Dalam Sistem Hukum Pidana Indonesia." Ius Quia Iustum Law Journal 21, no. 1 (n.d.): 81-95.

Faisal, Faisal, and Muhammad Rustamaji. "Perspektif Hukum Pidana Dalam Polemik Pengajuan Sumpah Advokat: Telaah Putusan Mahkamah Konstitusi Nomor 35/PUU-XVII/2018 Atas Surat Ketua Mahkamah Agung RI Nomor 73/KMA/HK. 01/IX/2015." Jurnal Hukum Ius Quia Iustum 27, no. 3 (2020): 45880.

Fajrin, Yaris Adhial. "Reconstruction of Castration Sanction Formulation in The Perspective of Indonesian Criminal Law Renewal." Jurnal Dinamika Hukum 19, no. 2 (2019): 389-406.

Farikhah, Mufatikhatul. "Konsep Judicial Pardon (Pemaafan Hakim) Dalam Masyarakat Adat Di Indonesia." Jurnal Media Hukum 25, no. 1 (2016): 81-92.

Febriansyah, Ferry Irawan, and Halda Septiana Purwinarto. "Pertanggungjawaban Pidana Bagi Pelaku Ujaran Kebencian Di Media Sosial." Jurnal De Jure 20, no. 2 (2020): 177-88.

Gunarto, Marcus Priyo. "Asas Keseimbangan Dalam Konsep Rancangan UndangUndang Kitab Undang-Undang Hukum Pidana." Mimbar Hukum-Fakultas Hukum Universitas Gadjah Mada 24, no. 1 (2012): 83-97.

Krismiyarsi, Krismiyarsi. "The Paradox of Positivistic View and Progressive Law of Criminal Law Enforcement in Indonesia." Jurnal Media Hukum 20, no. 2 (2013).

Marbun, Rocky. "Grand Design Politik Hukum Pidana Dan Sistem Hukum Pidana Indonesia Berdasarkan Pancasila Dan Undang-Undang Dasar Negara Republik Indonesia 1945." Padjadjaran Journal of Law 1, no. 3 (2014).

Moeljatno. Fungsi Dan Tujuan Hukum Pidana Indonesia. PT. Bina Aksara, Jakarta, 1985.

Muhaimin, Muhaimin. "Restoratif Justice Dalam Penyelesaian Tindak Pidana Ringan." Jurnal Penelitian Hukum De Jure 19, no. 2 (June 26, 2019): 185. 
https://doi.org/10.30641/DEJURE.2019.V19.185-206.

Nurahman, Adiansyah, and Eko Soponyono. "Asas Keseimbangan Dalam Rancangan Kitab Undang-Undang Hukum Pidana Sebagai Upaya Pembaharuan Hukum Pidana Yang Berkeadilan." Pandecta Research Law Journal 14, no. 2 (2019): 100106.

Nurdin, Fransiskus Saverius. "REKONSTRUKSI ASAS LEGALITAS DALAM HUKUM PIDANA BERDASARKAN PRINSIP KEADILAN.” Refleksi Hukum: Jurnal Ilmu Hukum 1, no. 1 (2016): 1-14.

Rahmat, Diding. “Formulasi Kebijakan Pidana Denda Dan Uang Pengganti Dalam Penegakan Tindak Pidana Korupsi Di Indonesia." Jurnal IUS Kajian Hukum Dan Keadilan 8, no. 1 (2020): 79-88.

Rustamaji, Muhammad. "Biomijuridika: Pemikiran Ilmu Hukum Pidana Berketuhanan Dari Barda Nawawi Arief." Undang: Jurnal Hukum 2, no. 1 (2019): 193-223.

Sholehuddin. Sistem Sanksi Dalam Hukum Pidana Ide Dasar Double Track System Dan Implementasinya. Jakarta: Rajawali Press, 2003.

Suhariyanto, Budi. "Kedudukan Perdamaian Sebagai Penghapus Pemidanaan Guna Mewujudkan Keadilan Dalam Pembaruan Hukum Pidana." Jurnal Rechts Vinding: Media Pembinaan Hukum Nasional 6, no. 1 (2017): 1-19.

Toelle, Marthen H. "Kriminalisasi Ditinjau Dari Perspektif Teori Hukum Pidana (Criminal Law Theory)." Refleksi Hukum: Jurnal Ilmu Hukum 8, no. 2 (2014): 11532.

Utama, Tody Sasmitha Jiwa. “'HUKUM YANG HIDUP’DALAM RANCANGAN KITAB UNDANG-UNDANG HUKUM PIDANA (KUHP): ANTARA AKOMODASI DAN NEGASI." Masalah-Masalah Hukum 49, no. 1 (2020): 14-25.

Wibawa, Iskandar. "Pidana Kerja Sosial Dan Restitusi Sebagai Alternatif Pidana Penjara Dalam Pembaharuan Hukum Pidana Indonesia." Jurnal Media Hukum 24, no. 2 (2017): 105-14.

Yoserwan. "Fungsi Sekunder Hukum Pidana Dalam Penanggulangan Tindak Pidana Perpajakan." Jurnal Penelitian Hukum De Jure 20, no. 02 (2020). https://doi.org/http://dx.doi.org/10.30641/dejure.2020.V20.165-176.

Yulistyowati, Efi, Endah Pujiastuti, and Tri Mulyani. "Penerapan Konsep TRIAS POLITICA Dalam Sistem Pemerintahan Republik Indonesia: Studi Komparatif Atas Undang-Undang Dasar Tahun 1945 Sebelum Dan Sesudah Amandemen." Jurnal Dinamika Sosial Budaya 18, no. 2 (August 9, 2017): 328-38. https://doi.org/10.26623/JDSB.V18I2.580. 